\title{
Economic and Environmental Aspects of Technologies for Surface Treatment of Selected Wood-based Composites
}

\author{
Katarzyna Mydlarz, ${ }^{\mathrm{a}}$ Sławomir Mydlarz, ${ }^{\mathrm{b}, *}$ and Marek Wieruszewski ${ }^{\mathrm{c}}$ \\ Research for new solutions in the field of wood-based materials and \\ possibilities of their refinement is prompted by both market needs and \\ increasingly restrictive environmental regulations. Many opportunities in \\ this area are created by modern industrial technologies and constantly \\ improved varnishing products as well. The observed trend indicating the \\ usage of increasingly advanced technologies for the refining of wood- \\ based materials in plants producing these composites confirms such \\ activities and it creates new market opportunities. The correlations \\ between the consumption of varnishing materials and the VOC index \\ depending on the application technology were established. The economic \\ and environmental benefits of the refining process concerning wood- \\ based materials in their production plants were shown for both the \\ manufacturers of the refinished composites and their buyers.
}

Keywords: Wood-based materials; Wood composites; Refinement processing; Coating technologies; Efficiency of varnish materials use; Cost coefficients; Environment aspects

Contact information: a: Department of Law and Organization of Agribusiness Enterprises, Faculty of Economics, University of Life Sciences, Poznań, Poland; b: Teknos Sp. z o.o., Warszawa, Poland; c: Department of Wood-based Materials, Faculty of Forestry and Wood Technology, University of Life Sciences, Poznań, Poland; *Corresponding author: slawomir.mydlarz@teknos.com

\section{INTRODUCTION}

The continuous development of industrial production currently requires the implementation of multiple solutions aimed at limiting interference with the environment. This is necessary because of the realities of climate change and its consequences for nature. Hence, the ideas and decisions implemented in the area of product manufacturing need to comply with the requirements contained, inter alia, in environmental standards and European Union (EU) directives (Directive 2004/35/CE; Council Directive 1999/13/EC; Directive (EU) 2016/2284). Taking into account the above assumptions, the solution is to take such actions that will adapt the current manufacturing systems to the needs of the ecosystem.

One industry in which the above criteria are consistently implemented is the woodbased products industry. The primary idea behind the production of wood-based engineered materials is to create lumber pieces that would not have the defects of solid wood and to create greater opportunities for manufacturing products on an industrial scale (Oniśko 2011). When introducing new solutions in the field of wood-based materials, another important factor is the possibility of achieving, for the processed products, equal or higher durability in comparison to the starting material. When introducing new solutions in the field of wood-based materials, another important factor is the possibility of achieving durability equal to or higher than the starting material for processed products in each part 
of composites. Traditional wood-based materials often exhibit a lack of texture and high water absorption capacity ( $\mathrm{Yu}$ et al. 2020). Therefore, in further stages of their development, the physical parameters (e.g., resistance to biological corrosion or increased water resistance) have been enhanced and decorative values have been introduced using, among other methods, rotogravure printing, high pressure laminates (HPL) laminating, and continuous pressure laminates (CPL) production (Krystofiak et al. 2011; Badila et al. 2012).

Further development of decorative technologies has led to the creation of digital printing and technologies that improve the haptic properties of wood-based materials. However, "the most popular method for improving the stability and appearance of woodbased materials is the coating applications" (Erdinler et al. 2019).

There is also a possibility of applying nanotechnology in the field of finishing wood and wood-based materials, which interferes with the structure of molecular-scale finishing materials, improving their physical and chemical properties (Kaygin and Akgun 2008). Examples include $\mathrm{SiO}_{2}$ nanoparticles, which make coatings scratch-proof, $\mathrm{ZnO}$ and $\mathrm{TiO}_{2}$ or iron oxide nanoparticles that protect the wood from UV radiation, and silver nanoparticles that have antibacterial properties (Zbieć et al. 2010; Pappu and Thakur 2017; Papadopoulos et al. 2019). Although such materials have already been created, they are still not produced on an industrial scale, mainly for economic reasons.

Currently, one can observe a certain tendency in the modernization of wood-based materials that allows for large scale production of intermediate products involving complex processing and finishing while still at the manufacturing stage (No and Kim 2005, 2007; Caufield et al. 2010; Akkus et al. 2019; Papadopoulos and Taghiyari 2019; Egger 2020). An example of such a solution is a varnished furniture board produced based on mediumdensity fibreboard (MDF) material in a high gloss or deep matt version with an individual decorative character. Obtaining this type of finishing was for a long time been reserved for companies producing finished products, and the only way to obtain this effect was to use complicated technologies and painting in dust-proof chambers. The introduction of innovative coating technologies in plants producing wood-based materials allowed for the achievement of similar effects on a mass scale. Examples include printed or "high gloss" finished furniture elements. Technologies that enable such finishing are not accessible for many entities due to high costs of purchase (reaching even several million EURO) and use of process line (Budownictwob2b 2021). However, the purchase and implementation of this type of technology by companies can have a favourable net effect on the environment due to innovative and constantly modified solutions that reduce waste production and adapt the emissions of harmful substances to updated environmental guidelines. Therefore, the production of this type of product on an industrial scale creates an opportunity for other manufacturers to base their production on finished composite elements. With increased specialization and precision used in the new technologies, the quality of composites has become high and more visually and haptically similar to the materials found in nature. It is anticipated that the end of the current stage of development of wood-based composites will bring the introduction of plastics based on wood produced in 3D technology. As the latest research shows, it is already technically possible to obtain a material modelled on natural wood, although the stage of development is at an early stage of the process and requires further research and analysis (Tao et al. 2020).

The selected examples do not cover all of the possible and available market options utilizing the methods and technologies of improving manufacturing processes and products of the wood industry. Not only the composites themselves, but also the properties of 
coatings obtained through the use of innovative systems of surface finishing and refinement are subject to change (Pandey et al. 2012; Poaty et al. 2013; Allen et al. 2018; Nair et al. 2018). Literature studies on this topic confirm that wood-based panels finished using the latest highly specialized technologies have performance properties that are often superior to wood-based panels finished using classic spray methods (Krystofiak et al. 2011; Pandey et al. 2012; Dilik et al. 2015; Kimpel and Pirrung 2015).

The specificity of wood-based materials plays a key role in research to maintain or improve coating properties while reducing negative environmental impacts and increasing the efficiency of manufacturing processes. Therefore, transferring the refining processes of wood composites to industrial enterprises involved in their production increases the possibilities of improving both quality and economic indicators (De Hernandez and Cool 2008; Klemm et al. 2011; Ugulino and De Hernandez 2016; Erdinler et al. 2019).

Directions connected to the process of the innovative finishing of composites allow not only for the improvement of the attractiveness of products but also of the economic and environmental parameters in the enterprises (Acda et al. 2012; Dilik et al. 2015). Increasing the labor costs of wood-working and wood-based materials manufacturers, e.g., in Central and Eastern European countries (Sobczyk 2019), is forcing manufacturers to use higherprocessed materials in an attempt to reduce the share of these costs in the total cost of manufacturing the final product.

In recent literature on the topic of refining of wood-based materials, there is no detailed reference to the combined consideration of economic and environmental aspects. Studies on the economic elements of investments in process lines often face limitations due to confidential company data. Therefore, the determination of WBU (Water Borne Unit) was selected as the basis for conducting research in this area. This indicator allows for assessment of wood-based products refinement in an interdisciplinary way, which is an innovative approach to the topic. This article shows, directly and indirectly, the economic and environmental benefits achieved by wood-based plastics producers and finished product manufacturers (win-win).

\section{EXPERIMENTAL}

\section{Materials and Methods}

The research and analysis was conducted in 2020, based on market demand from furniture and wood-based material manufacturers. The paints used in the analyses were chosen from products manufactured in companies owned by Teknos Group Oy, Helsinki, Finland. In the solid content estimation analysis, the following products were used: Teknocoat Aqua Primer 1866-05 (primer 1) - used for HDF/MDF, Teknocoat Aqua Primer 1875-98 (primer 2) - used for HDF/MDF, Aquafiller 1100-00 (pirmer 3) - used for HDF/MDF, W/B Adhesive Coat 221-204-1001 (primer 4) - used for HDF/MDF, Teknocoat Aqua 2575-32 (WB Top Coat) recommended as top layer in door industry, and Alpocryl LE 5393 Base sealer/Alpocryl Klarlack 1495 (High gloss Top coat - used as high gloss SB system).

In the simulation of material costs, the following products were used: Teknocoat Aqua Primer 221-104 (primer for roller application used for MDF/HDF), Teknocoat Aqua Sealer 231-101 (sealer for roller application used for MDF/HDF), Teknocoat Aqua Primer 221-162 (special primer for roller application for HDF), Teknocoat Aqua Sealer 231-165 (special sealer for roller application used for HDF), UVILUX 651-152XX1 (UV Top Coat 
for roller application), Teknocoat Aqua Primer 1875-98 (primer/sealer for spraying application used on MDF/HDF), Teknocoat Aqua 2575-32 (WB Top Coat for spraying application recommended in door industry), Teknocoat Aqua Primer 224-162 (special spraying door skin primer), Teknocoat Aqua Sealer 234-165 (special spraying door skin sealer), and Alpocryl LE 5393/Alpocryl Klarlack 1495 (High gloss Top coat - used as high gloss SB system).

The products chosen to analyze are common products on the market, and their Technical Data Sheets\&Safety Data Sheet are available online (https://www.teknos.com/ and https://shop.feycotreffert.com/). These documents contain all data necessary to provide investigation. The further parts of the investigation were based on the technologies presented by TEKNOS and Barberan S.A., Barcelona, Spain (painting equipment producer) with support of the technical data sheet of chosen products.

The analysis was based on three basic groups of varnish materials: waterborne (WB), ultraviolet-cured (UV), and solventborne (SB). The vast majority of waterborne are single-component physical drying varnishes and in this process, in which water is involved, solvent evaporates. Their role in the wood industry began to grow after the EU introduced volatile organic compound (VOC) limits (Kimpel and Pirrung 2015). These restrictions have contributed to the reduction of solvent-based varnishes and, at the same time, have resulted in the technological development of waterborne products (Directive 2010/75/UE). The second group are UV varnishes. Those are products which, in order to cure, must be exposed to a UV radiation. As a result of exposure, due to a photoinitiator, a photochemical reaction is initiated and the product is cured within a maximum of a few seconds (the curing of standard UV products takes less than $1 \mathrm{~s}$ ) (Bruen et al. 2004). The UV products, in a vast majority, are designed for roller coating machines. The solids content in coating materials of approximately $99 \%$ has almost no negative impact on the VOC balance sheet of the company using this solution. However, the use of this type of product requires significant investments, mainly in the technology (Khelifa et al. 2016).

Both WB and UV products belong to the group of prospective products for the varnish industry (Kaiser 2019). The last analyzed group of varnishes are SB varnishes. At the turn of the $21^{\text {st }}$ century, those varnishes lost their importance due to the aforementioned pro-environmental decisions made by the EU (Kougoulis et al. 2012; Coatings 2020; Europa 2020). Their ease of use and the possibility of obtaining special effects still allows them to serve some functions in the industry. They still have a strong, established position in obtaining high-gloss effect in situations where waterborne products are difficult to utilize due to the interaction of water contained in them with a surface and problems with achieving high transparency combined with the hardness of the final coating required in polishing (Andersson 2011).

For the analysis, two refined wood-based materials with different end-use, produced on an industrial scale, were selected. These include "doorskin" panels (Homanit 2020) and varnished furniture boards. Both materials are finished in wet technologies (using varnish materials) (Biznesmeblowy 2019).

"Doorskin" panels are an example of a material that, in recent years, has been used on an increasingly wider scale for the production of interior doors. It is a material that is obtained by applying a specific varnish system on high-density fiberboard (HDF) board (Homanit 2020).

The application of this system in industrial production conditions is carried out using the technology of roller coating (on flat surfaces) and spraying or curtain coating (on rough surfaces). In roller coating technology, the material consumption is much lower than 
in the most commonly used technology, i.e. spray application. The distinguishing features of the roller coating, compared to the technology of spray application, is the lower amount of varnish used per $\mathrm{m}^{2}$ of material (approximately $100 \mathrm{gm} / \mathrm{m}^{2}$ using roller coating, vs. approximately 230 to $370 \mathrm{~g} / \mathrm{m}^{2}$ in the technology of spray application) (Teknos 2020a,b) with almost $100 \%$ efficiency during application. This affects the end level of production costs and increases the profitability of production. Moreover, this technology allows using rotogravure printing, by which it is possible to obtain imitations of the structure of, e.g., wood, stone, and other materials at the lowest technological cost (additional application of printing inks using rotogravure printing is approximately $8 \mathrm{~g} / \mathrm{m}^{2}$ ). However, this type of printing is only possible on flat surfaces (Teknos 2020a).

Varnished furniture board is made based on the classic MDF material, onto the surface of which a decorative coating in the form of varnish or melamine film and varnish is applied. Particularly important, for market needs, was the development of this type of technology that allows for the achievement of an extreme degree of gloss: deep matt and high gloss. Previously, these technologies, due to their time-consuming nature, were used to produce a narrow group of individual products. The appearance of the varnished board, especially a high gloss one, allowed manufacturers of final products to skip a number of technological operations. In the case of this material, it is also possible to use the most economical roller coating application. Based on the technological guidelines, the high gloss effect on MDF with melamine film can be achieved by applying approximately $120 \mathrm{~g} / \mathrm{m}^{2}$ of varnish material (Barberan 2020). To achieve a similar effect using spray application technology, one has to calculate a minimum weight of $300 \mathrm{~g} / \mathrm{m}^{2}$ (Feycotreffert 2020a).

The application time and the drying time of the varnishes are also important factors when choosing the appropriate coating technology. In the case of the roller coating process on the line, it usually takes 2 to 10 minutes to apply the full paint system to the raw element. After this time the component is ready for further processing. In the case of spraying technology with forced air-drying, one cycle may take several tens of minutes (usually 30 to 60 minutes) with optional cooling of the painted elements. Spray coating technology using natural drying often requires the next coat to be applied during the next work shift or on the following day.

The selection of wood composites was made from the products offered by manufacturers who belong to the group of leading European wood industry concerns with global commercial reach. Selected products are prospective materials for companies in the furniture and construction industry in the field of joinery and interior design. Due to the selective availability of information, only selected cost-creating factors occurring at the refinement stage of "doorskin" panels and varnished furniture board were analyzed in detail. These include the type of varnish material and coating technology. Data analysis and descriptive analysis were used for both these wood-based materials. A correlation analysis of the studied parameters was used to investigate the relationship between the analysed factors, such as the type of paint coating and the VOC level.

\section{Material Flows under Study}

The use of highly processed composites by the companies producing final products stimulates the transfer of the pre-refinement stage to the producer of wood-based materials and thus accelerates the process of production in the companies producing final products. Transferring these operations resulted in the modification of the supply chain. In Fig. 1, one can see the differences between the standard supply chain, in which the manufacturer of final products performs the activities connected to the production on their own, vs. the 
modified supply chain, in which the pre-refinement is performed by the manufacturer of wood-based materials.

Standard supply chain

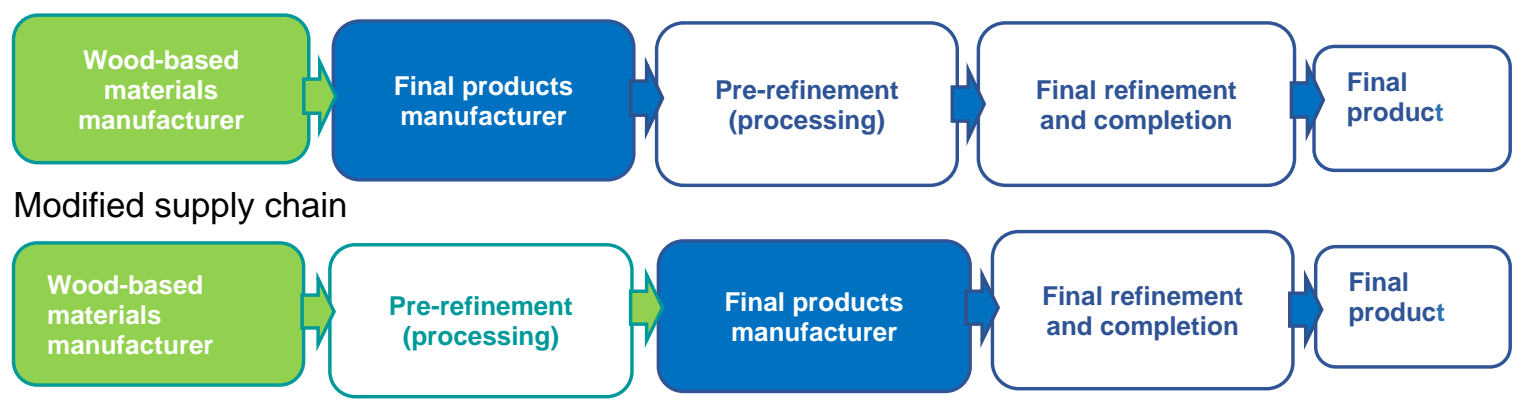

Fig. 1. Standard and modified supply chain in companies producing final products

The authors' aim is to show that the modification of the supply chain can influence the optimization of the material costs of wood composites.

\section{RESULTS}

The analysis of varnish products used for finishing selected wood-based materials was conducted based on a comparative model created by the authors. The analyzed groups of varnish products were $\mathrm{WB}, \mathrm{SB}$, and $\mathrm{UV}$, which are most often used for finishing selected wood-based materials. To determine the selected cost-creating factors occurring in the refinement process of wood-based materials, it was necessary to refer to the current prices of varnish products used for their finishing (Kelly and Bonner 2019). Because the prices of varnish products for manufacturing on the European market are considered to be proprietary knowledge, an American study containing current market prices for $\mathrm{WB}, \mathrm{SB}$, and UV products, analyzed in this paper, as well as product data sheets of identical products to the ones on the European market were used for the analyses. The data sheets were used to determine the level of solids in the analyzed varnish products. Based on the prices of products and the content of solids in products from the American market and the content of solids in products from the European market, coefficients were determined that allow establishing the predicted cost of WB, SB, and UV varnish products, which are used for finishing selected wood-based materials manufactured on the European market, for analysis.

The first stage was to determine, based on data sheets of varnish products, the average content of solids in the analyzed WB varnish products. In the case of the weight ratio stated in the product data sheet - Primer 4 (Teknos 2020c), the conversion into a volume ratio was made. Because the prices of varnish products were given in dollars per unit of volume, it was necessary to convert the weight of solids into the volume of solids. Table 1 presents the content of solids in the analyzed WB varnish products. Using the average content of solids, calculated as an arithmetic mean of solids by volume from all five products contained in Table 1 , the $W B_{\mathrm{EU}}$ value $=38.3 \%$ for $\mathrm{WB}$ products commonly available on the European market was obtained. 
Table 1. Content of Solids in the Analyzed WB Varnish Products

\begin{tabular}{|c|c|c|c|c|}
\hline Product & $\begin{array}{c}\text { Solids by } \\
\text { Volume } \\
(\%)\end{array}$ & $\begin{array}{c}\text { Solids by } \\
\text { Weight } \\
(\%)\end{array}$ & $\begin{array}{c}\text { Product } \\
\text { Thickness } \\
\left(\mathrm{g} / \mathrm{cm}^{3}\right)\end{array}$ & $\begin{array}{c}\text { VOC Value } \\
\text { Declared } \\
{[\mathrm{K}]} \\
\left(\mathrm{g}^{\mathrm{d}} \mathrm{dm}^{3}\right)\end{array}$ \\
\hline Primer 1 & 42.0 & - & - & 47 \\
\hline Primer 2 & 40.0 & - & - & 35 \\
\hline Primer 3 & 38.0 & - & - & 33 \\
\hline Primer 4 & 37.5 & 60 & 1.6 & 51 \\
\hline WB Top Coat & 34.0 & - & - & 8 \\
\hline $\begin{array}{c}\text { Average WBE Solids } \\
\text { Content }\end{array}$ & 38.3 & - & - & \\
\hline
\end{tabular}

Source: Elaboration based on product technical sheets: Teknos 2020c; Teknos 2020d; Teknos 2020e; Teknos 2020f; Teknos 2020g

Based on the average content of solids and the content given in the baseline study to which the authors refer: $W B_{U S}=27 \%$ in the same type of products available on the American market, the conversion factor of solids was determined (Eq. 1),

$$
S_{\mathrm{WB}}=W B_{\mathrm{EU}}: W B \mathrm{US}
$$

where $S_{\mathrm{WB}}$ is the conversion factor for WB products, $W B \mathrm{EU}$ is the average content of solid substances present in WB varnish products on the European market (\%), and $W B_{\mathrm{US}}$ is the average content of solid substances present in WB varnish products on the American market $(\%)$. As calculated, $S_{\mathrm{WB}}$ is 1.42 .

The conversion factor of solids for SB varnish products was determined in a similar way. In the case of both analyzed SB products, the conversion from weight to volume ratio was made. Table 2 presents the content of solids in the analyzed SB varnish products.

Table 2. Content of Solids in the Analyzed SB Varnish Products

\begin{tabular}{|c|c|c|c|c|}
\hline Product & $\begin{array}{c}\text { Solids by } \\
\text { Volume }\end{array}$ & Solids by Weight & $\begin{array}{c}\text { Product } \\
\text { Thickness }\end{array}$ & {$[\mathrm{K}]$} \\
\hline \multicolumn{2}{|c|}{$(\%)$} & 49 & 1.155 & $\left(\mathrm{~g} / \mathrm{cm}^{3}\right)$ \\
\hline Base - Sealer & 42.5 & 49 & 0.99 & 592 \\
\hline High Gloss Top Coat & 48.5 & & & 519 \\
\hline $\begin{array}{c}\text { Average SBEu Solids } \\
\text { Content }\end{array}$ & 45.5 & & \\
\hline
\end{tabular}

Source: Authors' own study based on product technical sheets: Feycotreffert 2020a; Feycotreffert $2020 \mathrm{~b}$

Based on the obtained arithmetic mean of the content of solid substances $S B_{\mathrm{EU}}=$ $45.5 \%$ by volume and the value given in the base study $S B$ US $=18 \%$, to which the authors refer, the $S_{\mathrm{SB}}$ conversion factor was obtained using Eq. 2,

$$
S_{\mathrm{SB}}=S B_{\mathrm{EU}}: S B_{\mathrm{US}}
$$

where $S_{\mathrm{SB}}$ is the conversion factor for SB products, $S B \mathrm{EU}$ is the average content of solid substances present in SB varnish products on the European market (\%), and SBUs is the average content of solid substances present in SB varnish products on the American market $(\%)$. As calculated, $S_{\mathrm{SB}}$ is 2.53 .

In the next stage, the prices of varnish products in American gallons (unit of volume in the USA) were converted into prices in $\$$ per $\mathrm{dm}^{3}$ - a unit applicable in the European 
metric system (American gallon for liquids $=231$ cubic inches $=3.785411784 \mathrm{dm}^{3}$ ) (Metric-conversions). The next step was to determine the prices of the expected WB, SB, and UV products using the previously determined conversion factors for solids (S). Due to identical values given in the analyzed study and technical data sheets for the UV product (Teknos 2020h), the value of this conversion factor was set at $S_{\mathrm{UV}}=1$. For WB and SB products, previously determined conversion factors $S_{\mathrm{WB}}$ and $S_{\mathrm{SB}}$ were used for calculations. The predicted price was determined based on Eq. 3,

$$
P_{\mathrm{P}}=P \times S
$$

where $P$ P is the expected price $(\$), P$ is the price for $1 \mathrm{dm}^{3}$ of varnish product $(\$)$, and $S$ is the conversion factor.

Then, the waterborne unit (WBU) was established, which will be the basis for further calculations. The starting point for determining this unit was the selection of the pattern for which the WB product was selected because of its largest share in the analyzed application technologies. It was further correlated with UV varnish material and SB product. The value of this standard for a water-dilutable product was symbolically assumed to be $1\left(1 \mathrm{dm}^{3} \mathrm{WB}=1 \mathrm{WBU}\right)$. The calculation system introduced is shown in Eq. 4:

$$
W B U=P_{\mathrm{P}}: P_{\mathrm{PWB}}
$$

The list of converted prices and values of selected varnish materials is presented in Table 3.

Table 3. Prices and Values of Varnish Products

\begin{tabular}{|c|c|c|c|c|c|}
\hline $\begin{array}{c}\text { Type of } \\
\text { Product }\end{array}$ & $\begin{array}{c}\text { Price per } \\
\text { Gallon }\end{array}$ & $\begin{array}{c}\text { Price per } \\
\text { Litre } \\
{[\mathrm{P}]}\end{array}$ & $\begin{array}{c}\text { Conversion } \\
\text { Factor of } \\
\text { Solids }[\mathrm{S}]\end{array}$ & $\begin{array}{c}\text { Expected } \\
\text { Price } \\
{\left[P_{\mathrm{P}}\right]}\end{array}$ & $\begin{array}{c}\text { Value Expressed } \\
\text { in WBU Units } \\
{[\mathrm{U}]}\end{array}$ \\
\cline { 2 - 6 } & \multicolumn{2}{|c|}{$(\$)$} & - & $\left(\$\right.$ for $\left.1 \mathrm{dm}^{3}\right)$ & - \\
\hline SB & 11.71 & 3.09 & 2.53 & 7.81 & 1.38 \\
\hline WB & 15.13 & 4.00 & 1.42 & 5.68 & 1 \\
\hline UV & 51.24 & 13.53 & 1 & 13.53 & 2.38 \\
\hline
\end{tabular}

Source: Authors' own study based on Metric Conversions (2020)

Based on selected application technologies for varnish products and the values given in the WBU units for the varnish products under consideration, simulation of material costs was performed based on cost coefficients for flat and profiled "doorskin" panels. Based on the product of the value expressed in WBU units (Table 3) and the quantity of applied varnish material [G] (Table 4) resulting from technological recommendations, cost coefficients $W_{\mathrm{k}}$ were established for the technologies of applying varnish products under consideration (Eq. 5),

$$
W_{\mathrm{k}}=U \times G
$$

where $W_{\mathrm{k}}$ is the cost factor, $U$ is the value expressed in WBU units, and $G$ is the quantity of varnish material applied (coating weight) $\left(\mathrm{g} / \mathrm{m}^{2}\right)$. Additionally, the VOC value was determined for individual varnish materials based on Eq. 6,

$$
V=G \times K: 1000
$$

where $V$ is the VOC value $\left(\mathrm{g} / \mathrm{m}^{2}\right)$, and $K$ is the VOC value declared by manufacturers of varnish products. 
The results are listed in Tables 4 and 5.

Table 4. Simulation of Material Costs Based on Cost Coefficients [ $\left.W_{k}\right]$ for Flat "Doorskin" Panels

\begin{tabular}{|c|c|c|c|c|c|c|c|c|}
\hline \multirow[b]{2}{*}{ Product } & \multirow{2}{*}{$\begin{array}{l}\text { Value } \\
\text { Expressed } \\
\text { in WBU } \\
\text { Units }(U)\end{array}$} & \multicolumn{2}{|c|}{$\begin{array}{c}\text { Technology of } \\
\text { Roller Application }\end{array}$} & \multicolumn{2}{|c|}{$\begin{array}{c}\text { Mixed } \\
\text { Technology } \\
\text { (Roller + Spray) }\end{array}$} & \multicolumn{2}{|c|}{$\begin{array}{l}\text { Technology of } \\
\text { Spray } \\
\text { Application }\end{array}$} & \multirow{2}{*}{$\begin{array}{c}\text { VOC } \\
{[\mathrm{V}]}\end{array}$} \\
\hline & & $\begin{array}{c}\text { Coating } \\
\text { Weight } \\
{[\mathrm{G}]} \\
\left(\mathrm{g} / \mathrm{m}^{2}\right)\end{array}$ & $\left(W_{\mathrm{k}}\right)$ & $\begin{array}{c}\text { Coating } \\
\text { Weight } \\
{[\mathrm{G}]} \\
\left(\mathrm{g} / \mathrm{m}^{2}\right)\end{array}$ & {$\left[W_{k}\right]$} & $\begin{array}{c}\text { Coating } \\
\text { Weight } \\
{[\mathrm{G}]} \\
\left(\mathrm{g} / \mathrm{m}^{2}\right)\end{array}$ & {$\left[W_{k}\right]$} & \\
\hline $\begin{array}{c}\text { Primer for } \\
\text { Roller } \\
\text { Application, } \\
\text { WB Type } \\
\end{array}$ & 1.00 & 50 & 50 & & & & & 2.55 \\
\hline $\begin{array}{l}\text { Undercoat } \\
\text { for Roller } \\
\text { Application, } \\
\text { WB Type }\end{array}$ & 1.00 & 40 & 40 & & & & & 2.04 \\
\hline $\begin{array}{c}\text { Special } \\
\text { Primer for } \\
\text { Roller } \\
\text { Application, } \\
\text { WB Type }\end{array}$ & 1.00 & & & 20 & 20 & & & 1.02 \\
\hline $\begin{array}{l}\text { Special } \\
\text { Undercoat } \\
\text { for Roller } \\
\text { Application, } \\
\text { WB Type }\end{array}$ & 1.00 & & & 75 & 75 & & & 3.83 \\
\hline $\begin{array}{c}\text { Topcoat for } \\
\text { Roller } \\
\text { Application, } \\
\text { UV Type }\end{array}$ & 2.38 & 10 & 23.8 & & & & & $0^{*}$ \\
\hline $\begin{array}{c}\text { WB } \\
\text { Undercoat } \\
\text { Spray }\end{array}$ & 1.00 & & & & & $175^{\star *}$ & 175 & 6.65 \\
\hline $\begin{array}{c}\text { WB } \\
\text { Topcoat } \\
\text { Spray }\end{array}$ & 1.00 & & & $175^{\star *}$ & 175 & $175^{\star *}$ & 175 & 1.4 \\
\hline Total & & & 113.8 & & 270.0 & & 350.0 & \\
\hline VOC & otal & $\begin{array}{r}4.59(2.5 \\
+\end{array}$ & +2.04 & $\begin{array}{r}6 . \\
(1.02+ \\
1\end{array}$ & $83+$ & $\begin{array}{r}8.0 \\
(6.65\end{array}$ & 1.4) & \\
\hline
\end{tabular}

Source: Authors' own elaboration based on Proszyk 1999; Teknos 2020a; Teknos 2020b; ${ }^{*}$ Due to an extremely low VOC content for UV varnishes, a value of 0 was used for the calculation.

**The quantity of applied varnish material (coating weight) suggested by the manufacturers increased by the smallest possible loss factor with spray application (1.3). 
Table 5. Simulation of Material Costs Based on $W_{k}$ for Profiled "Doorskin" Panels

\begin{tabular}{|c|c|c|c|c|c|c|}
\hline \multirow{3}{*}{ Product } & \multirow{3}{*}{$\begin{array}{l}\text { Value } \\
\text { Expressed } \\
\text { in WBU } \\
\text { Units }\end{array}$} & \multicolumn{4}{|c|}{$\begin{array}{c}\text { Technology of Spray Application - (Surface Pre- } \\
\text { refinement) }\end{array}$} & \multirow{3}{*}{$\begin{array}{c}\text { VOC } \\
{[\mathrm{V}]} \\
\left(\mathrm{g} / \mathrm{m}^{2}\right)\end{array}$} \\
\hline & & \multicolumn{2}{|c|}{$\begin{array}{l}\text { At the Manufacturer of } \\
\text { Plastic }\end{array}$} & \multicolumn{2}{|c|}{$\begin{array}{l}\text { At the Manufacturer } \\
\text { of the Final Product }\end{array}$} & \\
\hline & & $\begin{array}{c}\text { Coating Weight } \\
\text { [G] } \\
\left(\mathrm{g} / \mathrm{m}^{2}\right)\end{array}$ & {$\left[W_{\mathrm{k}}\right]$} & $\begin{array}{l}\text { Coating } \\
\text { Weight } \\
(\mathrm{G}) \\
\left(\mathrm{g} / \mathrm{m}^{2}\right)\end{array}$ & {$\left[W_{k}\right]$} & \\
\hline $\begin{array}{l}\text { Special Primer for } \\
\text { Spraying }\end{array}$ & 1.00 & $39^{* *}$ & 39 & & & 1.98 \\
\hline $\begin{array}{c}\text { Special } \\
\text { Undercoat (for } \\
\text { Spraying on Door } \\
\text { Skin Panels) }\end{array}$ & 1.00 & $117^{\star \star}$ & 117 & & & 5.96 \\
\hline $\begin{array}{l}\text { Standard } \\
\text { Undercoat for } \\
\text { Spraying }\end{array}$ & 1.00 & & & $182^{* *}$ & 182 & 6.91 \\
\hline $\begin{array}{l}\text { Topcoat for } \\
\text { Spraying }\end{array}$ & 1.00 & $182^{\star *}$ & 182 & $182^{\star \star}$ & 182 & 1.45 \\
\hline Total & & 238 & 238 & 364 & 364 & \\
\hline \multicolumn{2}{|c|}{ VOC Total } & \multicolumn{2}{|c|}{$9.39(1.98+5.96+1.45)$} & \multicolumn{2}{|c|}{$8.36(6.91+1.45)$} & \\
\hline
\end{tabular}

Source: Authors' own elaboration based on Proszyk 1999; Teknos 2020a; Teknos 2020b **The quantity of applied varnish material (coating weight) suggested by the manufacturers increased by the smallest possible loss factor with spray application (1.3).

The next activity was to simulate material costs based on cost coefficients for high gloss coated MDF furniture as an example of the technology of industrial application on rollers high gloss Hot Coating ${ }^{\circledR}$ and spray technology. The summary of the simulation results is included in Table 6.

Table 6. Simulation of Material Costs Based on $W_{k}$ for High Gloss Coated MDF Board

\begin{tabular}{|c|c|c|c|c|c|c|}
\hline \multirow{2}{*}{ Product } & \multirow{2}{*}{$\begin{array}{c}\text { Value } \\
\text { Expressed } \\
\text { in WBU } \\
\text { Units [U] }\end{array}$} & \multicolumn{2}{|c|}{$\begin{array}{c}\text { Technology of Roller } \\
\text { Application (High Gloss Hot } \\
\text { Coating® - Example System) }\end{array}$} & \multicolumn{2}{|c|}{$\begin{array}{c}\text { Technology of Spray } \\
\text { Application }\end{array}$} & \multirow{2}{*}{$\begin{array}{c}\text { VOC } \\
{[\mathrm{V}]}\end{array}$} \\
\hline & & $\begin{array}{l}\text { Coating Weight [G] } \\
\qquad\left(\mathrm{g} / \mathrm{m}^{2}\right)\end{array}$ & {$\left[W_{k}\right]$} & $\begin{array}{c}\text { Coating } \\
\text { Weight [G] } \\
\left(\mathrm{g} / \mathrm{m}^{2}\right)\end{array}$ & {$\left[W_{\mathrm{k}}\right]$} & \\
\hline $\begin{array}{c}\text { Hot Coating } \\
\text { Undercoat }\end{array}$ & 2.38 & 20 & 47.6 & & & $0^{*}$ \\
\hline UV Undercoat & 2.38 & 40 & 95.2 & & & $0^{*}$ \\
\hline UV Topcoat & 2.38 & 60 & 142.8 & & & $0^{*}$ \\
\hline SB Undercoat & 1.38 & & & 125 & 172.5 & 102.12 \\
\hline SB Topcoat & 1.38 & & & 175 & 241.5 & 125.33 \\
\hline Total & & & 285.6 & & 414.0 & \\
\hline \multicolumn{2}{|c|}{ VOC Total } & \multicolumn{2}{|l|}{$0(0+0+0)$} & \multicolumn{2}{|c|}{$\begin{array}{c}227.45(102.12+ \\
125.33)\end{array}$} & \\
\hline
\end{tabular}

Source: Authors' own elaboration based on Barberan 2020; Feycotreffert 2020a; Feycotreffert 2020b; Kleiberit 2020;

*Due to an extremely low VOC content for UV varnishes, a value of 0 was assumed for the calculation. 
Figure 2 shows the verification of the relation between the varnish application [G] and the VOC coefficient [V]. The correlation value was 0.62 . The increase in varnish material consumption occurred when switching from roller to spray application technology. The relationship between the WBU parameter and the varnish application rate [G] was negative (-0.43).

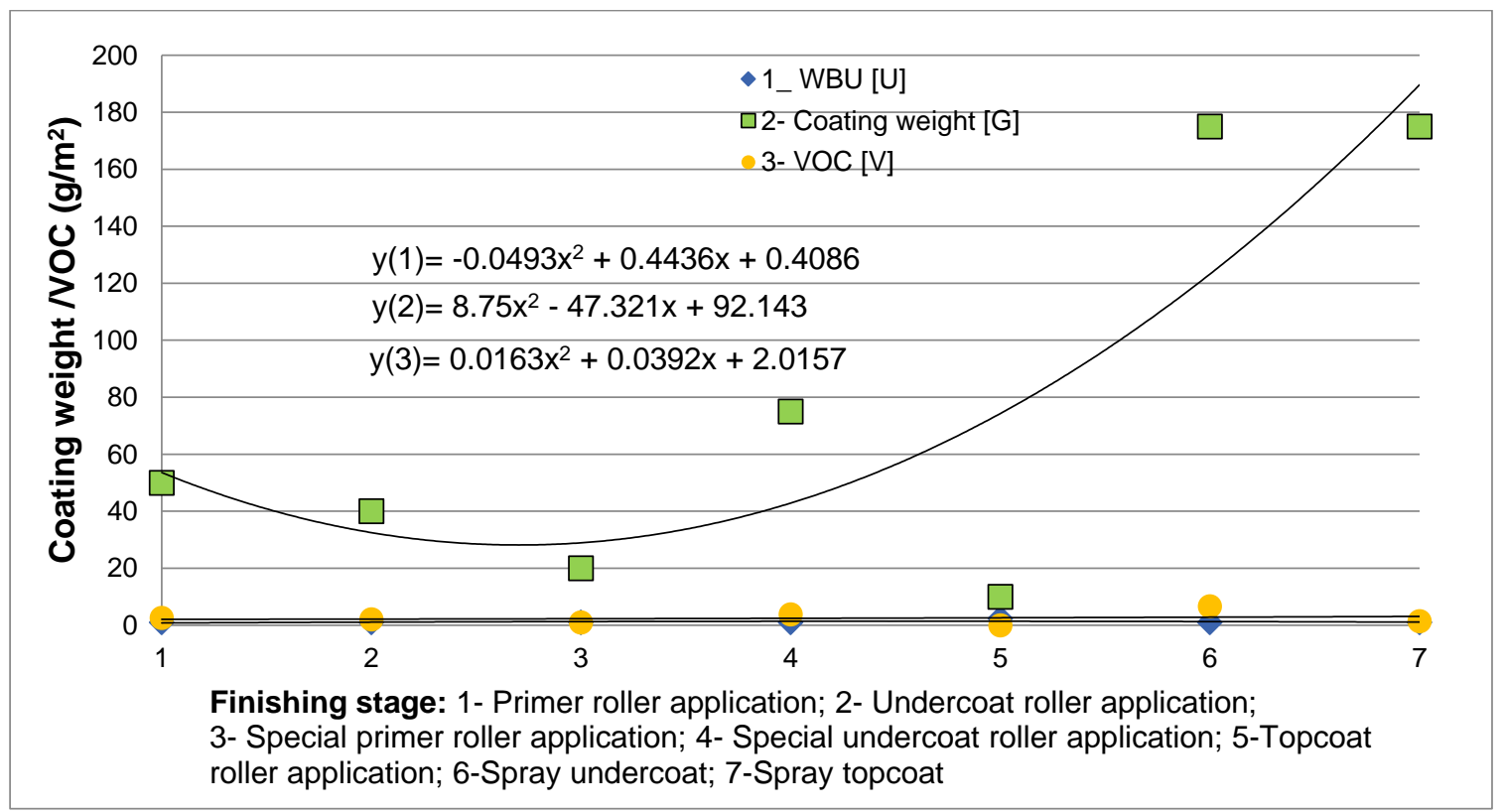

Fig. 2. Relationships between selected parameters at individual stages of finishing the flat "doorskin" products

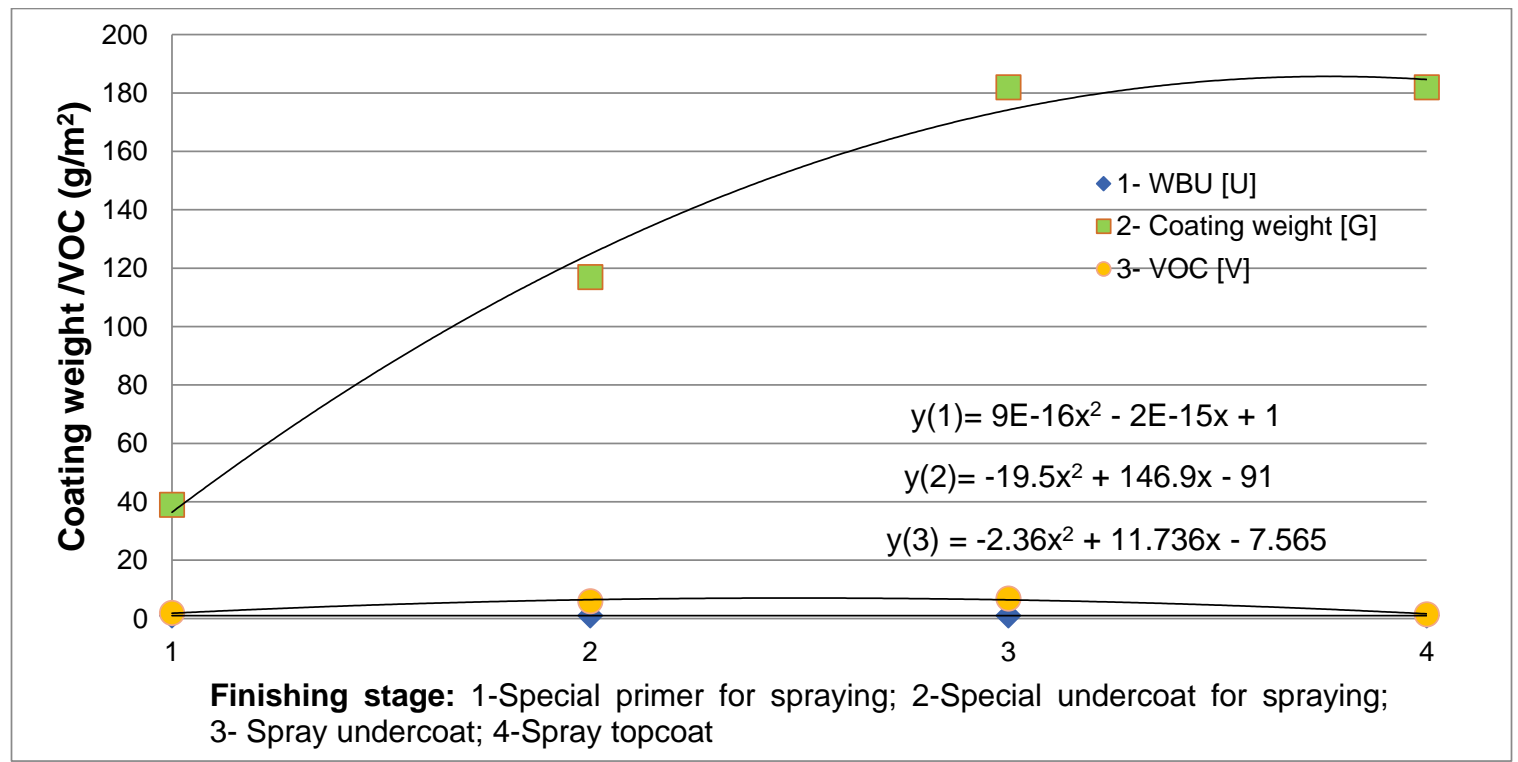

Fig. 3. Relationships between selected parameters at particular stages of finishing the profiled "doorskin" products

In the studies concerning the relationship between the consumption values of individual varnish materials [G] for profiled "doorskin" systems, a moderate correlation 
with the VOC emission factor [V] of 0.31 was confirmed. The relationship shown in Fig. 3 does not indicate any correlation with the WBU coefficient for both coating at material consumption and VOC emissions.

In the studies on the relationship between the consumption values of the varnish materials [G] for high-gloss painted MDF boards, a high correlation with the VOC coefficient [V] of 0.96 was confirmed. The relationship shown in Fig. 4 shows the inverse correlation of WBU with both paint material consumption [G] and VOC emissions (-0.93 and -0.99). An increase in emissions occurred with the application of paint coatings applied by spraying.

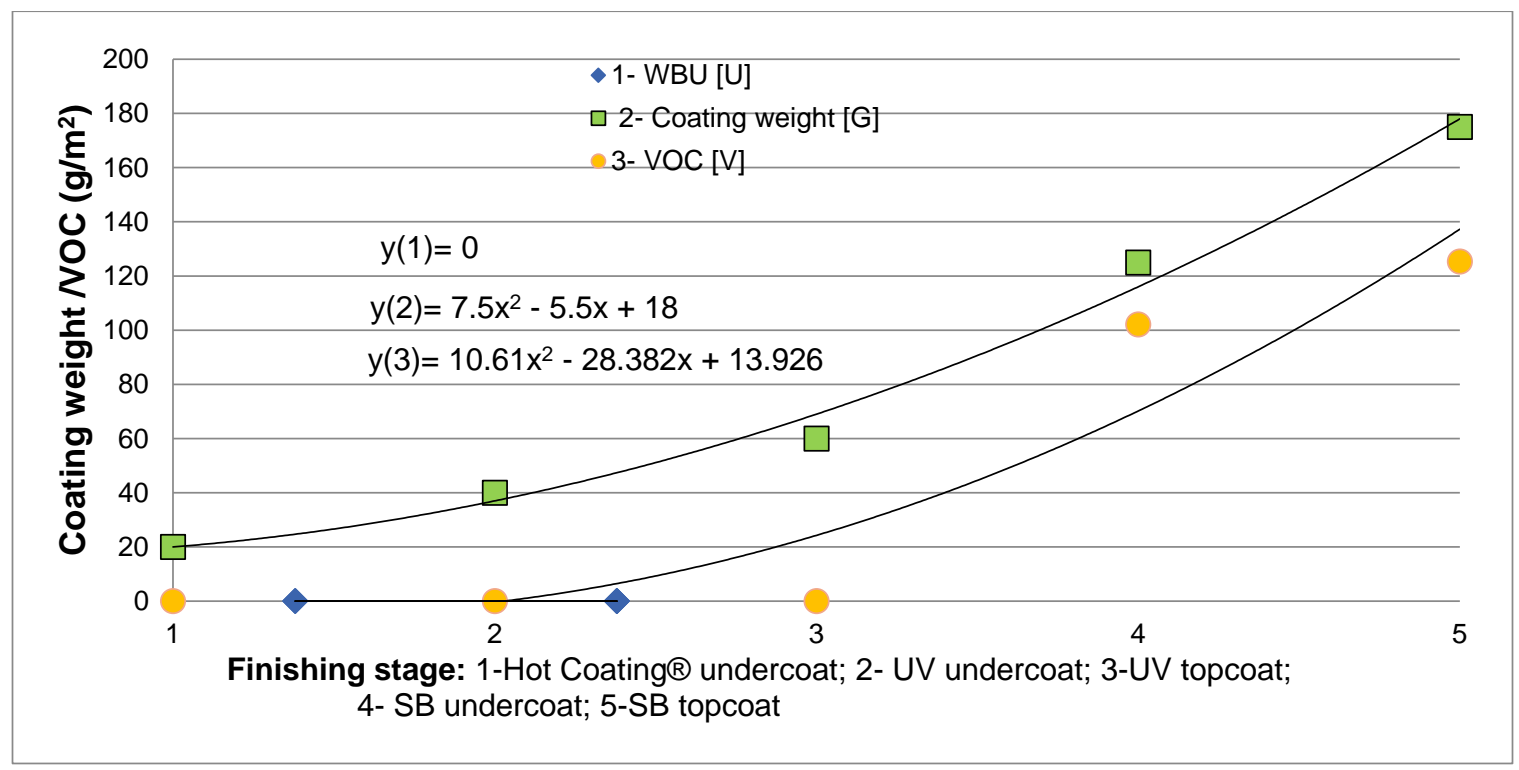

Fig. 4. Relationships between selected parameters at particular stages of finishing the MDF highgloss products

\section{DISCUSSION}

The simulation of material costs of the analyzed varnish products applied in the technologies under consideration, carried out based on cost coefficients, showed a lower value of the cost coefficient for the manufacturer of plastic than for the manufacturer of the final product. The lowest cost of refining is characteristic of "doorskin" type wood composites produced on the basis of full roller application technology. The cost reduction in this technology compared to the spray technology according to calculations was approximately 68\% (Table 4). For priming "doorskin" panels at a wood-based materials manufacturer both on rollers and by spraying (Tables 4 and 5), as well as in the case of furniture board refinement with/in the high gloss Hot Coating® technology (Table 6), a lower $W_{\mathrm{k}}$ factor (in the range of 65 to $77 \%$ ) was also observed compared to the spraying technology.

Analyzing the level of VOC emissions from refining layers, it was found that in the case of "doorskin" flat panel refining technology, there was a linear increase in VOC emissions as the technology was converted from roller to spraying application (Table 4). For the "doorskin" spraying technology, no decrease in VOC emissions was observed when priming panels by a wood composite producer. The VOC emission at this plant was $11 \%$ 
higher than at the manufacturers of the finished product (Table 5), which was due to the higher VOC coefficient for the spray primer used by the wood composite manufacturer. In the opinion of the authors analyzing the given model, the deviation of $11 \%$ was minor and the VOC values in both cases could be treated as comparable. Comparing the VOC emission for furniture board coated with the use of the roller technology and SB spraying technology, a noticeable unit reduction in the VOC emission for the roller technology was observed.

In light of the data presented, it has been shown that for both cost and environmental reasons, the best solution in the process of refining wood composites is the use of roller application. The use of such composites is an element of responsible business management and, as a result, in great part reduces impact on the environment. Such a measure fits perfectly into the EU environmental policy. An additional aspect, the importance of which is growing yearly, is the reduction of direct labor costs by manufacturers of finished products. This is possible by moving the pre-refinement stage of wood-based materials to theirs manufacturer's plant. In specialized wood composite manufacturing companies, where most of the operations take place in a mechanized process line, the unit labor costs for pre-refinement operations are much lower than for finishing in the final product plants. Thus, the transfer of pre-refinement of wood-based materials to the companies producing them seems to be a necessity in the current market economy conditions. The continuous search for cost optimization and the proposed model may be a starting point for other technologies of surface refinement of wood composites.

The results of the analyses carried out confirm the validity of the application of the finishing refinement of wood-based materials by their producers. The presented results confirm the correlation of the use of integrated wood-based materials coating processes with the emission of VOC. The simplified model for the correlation of coating system and VOC emission, determined in this study, can be used to perform similar analyses for other surface finishing technologies.

Unfortunately, on the basis of the data collected, it was not possible to forecast the growth dynamics of the supply of wood-based products refined in the plants producing these products. It was also not possible to determine the actual costs of the analyzed technologies for finishing of wood-based products due to confidentiality of information necessary for their determination. However, the obtained results make it possible to state that it is only a matter of time before more already refined wood-based products will be introduced into the market. Thanks to the reference to both economic and environmental aspects, which are important for every enterprise operating in the market today, technical and technological works may gain a practical context.

\section{CONCLUSIONS}

1 The analyses indicated that from both an economic and environmental point of view it is justified to introduce an initial stage of surface finishing in companies producing these wood materials.

2 The lowest VOC emissions and the lowest consumption of paint materials are characterized by the roller coater application (coating technology used by the wood composites manufacturers). The highest VOC emissions and the highest consumption 
of paint materials are related to spraying technology, which is still the most popular method of coating among manufacturers of wood finished products.

3 The surface pretreatment of wood composites by their manufacturer guarantees the achievement and maintenance of high parameters and properties of pre-treated composite panels.

\section{ACKNOWLEDGMENTS}

This publication was financed by the Faculty of Economics of the Poznan University of Life Sciences.

\section{REFERENCES CITED}

Acda, M. N., Devera, E. E., Cabangon, R. J., and Ramos, H. J. (2012). "Effects of plasma modification on adhesion properties of wood," Int. J. Adhes. Adhes. 32(1) 70-75. DOI: 10.1016/j.ijadhadh.2011.10.003

Akkus, M., Akbulut, T., and Candan Z. (2019). “Application of electrostatic powder coating on wood composite panels using a cooling method. Part 1: Investigation of water intake, abrasion, scratch resistance, and adhesion strength," BioResources 14(4), 9557-9574. DOI: 10.15376/biores.14.4.9557-9574

Allen, N. S., McIntyre, R., Kerrod, J. M., Hill, C., and Edge, M. (2018). "Photostabilisation and UV blocking efficacy of coated macro and nano-rutile titanium dioxide particles in paints and coatings," J. Polym. Environ. 26(11), 4243-4257. DOI: 10.1007/s10924-018-1298-0

Andersson, A. (2011). "Characterisation of the influence of curing temperature on the properties of $2 \mathrm{~K}$ waterborne topcoat," (https://www.divaportal.org/smash/get/diva2:508108/FULLTEXT01.pdf), Accessed 08 Sept 2020.

Badila, M., Dolezel-Horwath, E., Zikulnig-Rusch, E. M., Schmidt, T., and Kandelbauer, A. (2012). "Evaluation of the compatibility between low pressure melamine (LPM) film printing substrates and inkjet inks," Eur. J. Wood Wood Prod. 70, 639-649. DOI: $10.1007 / \mathrm{s} 00107-012-0601-3$

Barberan (2020). "Coating, printing and drying systems," (https://files.hoechsmann.com/lexikon/pdf/original/bar_lackieren_drucken_2013_en. pdf?lang=de), Accessed 08 Sept 2020.

Biznesmeblowy (2019). "Nowa płyta lakierowana - perfekcyjny wygląd i wyjątkowa trwałość [New lacquered board - perfect appearance and exceptional durability]," (https://www.biznesmeblowy.pl/produkcja_mebli/116/nowa_plyta_lakierowana_perf ekcyjny_wyglad_i_wyjatkowa_trwalosc,16193.html), Accessed 27 Aug 2020.

Bruen, K., Davidson, K., Sydes, D. F. E., and Siemens, P. M. (2004). "Benefits of UVcurable coatings," European Coatings Journal 2004(4), pp 42-48.

Budownictwob2b (2021). "Pfleiderer uruchamia największą na świecie linię lakierniczą w technologii Hot Coating [Pfleiderer launches the world's largest coating line in Hot Coating technology]," (https://budownictwob2b.pl/wykanczanie/puls-branzy/19008pfleiderer-uruchamia-najwieksza-na-swiecie-linie-lakiernicza-w-technologii-hotcoating), Accessed 02 Feb 2021. 
Caufield, D. F., Clemons, C., and Rowell, R. M. (2010). "Wood thermoplastic composites," in: Sustainable Development in the Forest Products Industry, R. M. Rowell (ed.), Universidade Fernando Pesoa, Porto, Portugal, pp. 141-161.

Coatings (2020). "VOC product regulations," (https://www.coatings.org.uk/vocproductregulations.aspx), Accessed 08 Sept 2020.

De Hernandez, R. E., and Cool, J. (2008). "Evaluation of three surfacing methods on paper birch wood relation to water and solvent borne coatings performance," Wood Fiber Sci 40, 459-469, (https://wfs.swst.org/index.php/wfs/article/view/1185), Accessed 10 Feb 2021.

Dilik, T., Erdinler, S., Hazir, E., Koç, H., and Hiziroglu, S. (2015). “Adhesion strength of wood based composites coated with cellulosic and polyurethane paints," Adv. Mater. Sci. Eng. 1(5), article ID 745675. DOI: 10.1155/2015/745675

Egger (2020). "The history of Egger," Egger, (https://www.egger.com/shop/pl_PL/onas/nasza-grupa/historia), Accessed 08 Sept 2020.

Erdinler, E. S., Koc, K. H., Dilik, T., and Hazir, E. (2019). "Layer thickness performances of coatings on MDF: Polyurethane and cellulosic paints," MaderasCienc. Tecnol. 21(3), 317-326. DOI: 10.4067/S0718-221X2019005000304

Europa (2020). "Study on the potential for reducing emissions of volatile organic compounds (VOC) due to the use of decorative paints and varnishes for professional and non-professional use," (https:/ec.europa.eu/environment/air/pdf/paint_solvents/ decopaint.pdf), Accessed 02 Sept 2020.

European Council Directive 1999/13/EC (1999). “Council Directive 1999/13/EC of 11 March 1999 on the limitation of emissions of volatile organic compounds due to the use of organic solvents in certain activities and installations," European Union, Brussels, Belgium.

European Parliament and Council Directive 2004/35/CE (2004). "Directive 2004/35/CE of the European Parliament and of the Council of 21 April 2004 on environmental liability with regard to the prevention and remedying of environmental damage," European Union, Brussels, Belgium.

European Parliament and Council Directive 2010/75/UE (2010). "Directive 2010/75 / EU of the European Parliament and of the Council of 24 November 2010 on industrial emissions (integrated pollution prevention and control) text with EEA relevance," European Union, Brussels, Belgium.

European Parliament and Council Directive 2016/2284 (2016). Directive (EU) 2016/2284 of the European Parliament and of the Council of 14 December 2016 on the reduction of national emissions of certain atmospheric pollutants, amending Directive 2003/35/EC and repealing Directive 2001/81/EC,” European Union, Brussels, Belgium.

Feycotreffert (2020a). "Alpocryl Klarlack 1495 - [Technical data sheet. Safety data sheet], (https://shop.feycotreffert.com/product/969/ALPOCRYL\%20KLARLACK \%201495), Accessed 13 Sept 2020.

Feycotreffert (2020b). "ALPOCRYL LE 5393 - [Technical data sheet. Safety data sheet]," (https://shop.feycotreffert.com/product/235/ALPOCRYL\%20LE\%205393), Accessed 13 Sept 2020.

Homanit (2020). “Technical data sheet - HDF Homadur ${ }^{\circledR}$, , (https://www.homanit.pl/ pl/produkty/homadur_plyty_drzwiowe/homadur_plyty_drzwiowe.php), Accessed 27 Aug 2020. 
Kaiser, E. (2019). "Warum Wasserlacke? Vorurteile vs. Fakten," (https://www.holzhelden.de/2019/06/27/interview-warum-wasserlacke-vorurteile-vsfakten/), Accessed 08 Sept 2020.

Kaygin, B., and Akgun, E. (2008). "Comparison of conventional varnishes with nanolacke UV varnish with respect to hardness and adhesion durability," Int. J. Mol. Sci. 9(4), 476-485. DOI: 10.3390/ijms9040476

Kelly, M., and Bonner, M. (2019). "Comparison of coating coverage and applied cost for solvent-based, water-based and 100\% solids UV coating," UV+EB Technology, (https://uvebtech.com/articles/2019/comparison-of-coating-coverage-and-appliedcost-for-solvent-based-water-based-and-100-solids-uv-coating/), Accessed $02 \mathrm{Sept}$ 2020.

Khelifa, F., Habibi, Y., and Dubois, P. (2016). "Nanocellulose-based polymeric blends for coating applications," in: Multifunctional Polymeric Nanocomposites Based on Cellulosic Reinforcements, D. Puglia, E. Fortunati, and J. M. Kenny (eds.), William Andrew Publishing, Norwich, NY, USA, pp. 131-175. DOI: 10.1016/B978-0-32344248-0.00005-5

Kimpel, D., and Pirrung, F. (2015). "Novel UVA/HALS blend for high performance waterborne coatings," Paints and Varnishes 2015(5), 16-20.

Kleiberit (2020). "KLEIBERIT builds up a new market segment with "HotCoating"," (https://www.kleiberit.com/fileadmin/Content/Documents/EN/Articles/2013/HotCoati ng_PR_SurfaceMagazin_GB_US.pdf), Accessed 08 Sept 2020.

Klemm, D., Kramer, F., Moritz, S., Lindström, T., Ankerfors, M., Gray, D. (2011). "Nanocelluloses: A new family of nature-based materials," Angew Chemie Int Ed 50(24):5438-5466. DOI: 10.1002/anie.201001273

Kougoulis, J., Kaps, R., Walsh, B., Bojczuk, K., and Crichton, T. (2012). "Revision of EU European ecolabel and development of EU green public. Procurement criteria for indoor and outdoor paints and varnishes," (https://ec.europa.eu/environment/ecolabel/ documents/Paints\%20Background\%20Report.pdf), Accessed 02 Sept 2020.

Krystofiak, T., Lis, B., Proszyk, S., and Gaida, P. (2011). "Investigations upon some properties of surfaces of wood based materials finished with decorative foils in continuous technology," Annals of WULS-SGGW Forestry and Wood Technology 74, 249-253.

Metric Conversions (2020). "Metric conversions," (https://www.metricconversions.org/pl/objetosc/galony-amerykanskie-ciecze-do-litry.htm), Accessed 02 Sept 2020.

Nair, S., Nagarajappa, G. B., and Pandey K. K. (2018). “UV stabilization of wood by nano metal oxides dispersed in propylene glycol," J. Photochem. Photobiol. B 183, 110. DOI: 10.1016/j.jphotobiol.2018.04.007

No, B. Y., and Kim, M. G. (2005). "Curing properties of low level melamine-modified urea-formaldehyde particleboard binder resins studied with dynamic mechanical analysis (DMA)," J. Appl. Polym. Sci. 97(1), 377-389. DOI: 10.1002/app.21759

No, B. Y., and Kim, M. G. (2007). "Evaluation of melamine-modified urea-formaldehyde resins as particleboard binders," J. Appl. Polym. Sci. 106(6), 4148-4156. DOI: 10.1002/app. 26770

Oniśko, W. (2011). "Nowe generacje tworzyw drzewnych i nowoczesne technologie [New generations of wood-based composites and modern technologies]," (https://www.drewno.pl/artykuly/7524, nowe-generacje-tworzyw-drzewnych-inowoczesne-technologie.html), Accessed 29 Sept 2020. 
Pandey, K. K., Srinivas, K., and Salla, J. (2012). "Improvement of UV resistance of wood surfaces by using zinc oxide nanoparticles," Polym. Degrad. Stabil. 97(4), 592-596. DOI: 10.1016/j.polymdegradstab.2012.01.013

Papadopoulos, A. N., Bikiaris, D. N., Mitropoulos, A. C., and Kyzas, G. Z. (2019). "Nanomaterials and chemical modifications for enhanced key wood properties: A review," Nanomaterials-Basel 9(4), Article number 607. DOI: 10.3390/nano9040607

Papadopoulos, A. N., and Taghiyari, H. R. (2019). "Innovative wood surface treatments based on nanotechnology," Coatings 9(12), Article number 866. DOI: 10.3390/coatings9120866

Pappu, A., and Thakur, V. K. (2017). "Towards sustainable micro and nano composites from fly ash and natural fibers for multifunctional applications," Vacuum 146, 375385. DOI: 10.1016/j.vacuum.2017.05.026

Poaty, B., Riedl, B., Blanchet, P., Blanchard, V., and Stafford, L. (2013). "Improved water repellency of black spruce wood surfaces after treatment in carbon tetrafluoride plasmas," Wood Sci. Technol. 47(2), 411-422. DOI: 10.1007/s00226-012-0505-8

Proszyk, S. (1999). Technologia Tworzyw Drzewnych Część 2 [Wood-based Materials Technology Part 2], WSiP, Warszawa, Polska.

Sobczyk, S. (2019). "Koszty pracy w UE - komentarz MPiT do danych Eurostat [Labor costs in the EU-MPiT comment on Eurostat data]," (https://www.gov.pl/web/rozwoj/koszty-pracy-w-ue-komentarz-mpit-do-danycheurostat), Accessed 08 Sept 2020.

Tao, Y., Li, Z., and Li, P. (2020). "A design and fabrication method for wood-inspired composites by micro X-ray computed tomography and 3D printing," Appl. Sci. 10(4), Article number 1400. DOI: 10.3390/app10041400

Teknos (2020a). "Solutions for thin board - product portfolio," (https://www.teknos.com/globalassets/teknos.de/broschuren/flyer_a4_thin_board_po rtfolio_online_compr.pdf), Accessed 02 Sept 2020.

Teknos (2020b). "Interior doors from Porta KMI Poland," (https://www.teknos.com/plPL/painting-news/painting-wood-news-ligna-special-may-2017/teknos-solutions-forinterior-doors/), Accessed 31 Aug 2020.

Teknos (2020c). "Technical datasheet: W/B adhesive coat 221-204-1001," (https://www.teknos.com/globalassets/teknos.my/products/tds-wb/tm_221-2041001.pdf), Accessed 02 Sept 2020.

Teknos (2020d). "AQUAFILLER 1100-00 - Karta techniczna produktu [Technical data sheet], Karta charakterystyki [Safety data sheet]," (https://www.teknos.com/plPL/produkty/aquafiller-1100-00/), Accessed 13 Sept 2020.

Teknos (2020e). "TEKNOCOAT AQUA PRIMER 1875-98 - Karta techniczna produktu [Technical data sheet], Karta charakterystyki [Safety data sheet]," (https://www.teknos.com/pl-PL/produkty/teknocoat-aqua-primer-1875-98/), Accessed 13 Sept 2020.

Teknos (2020f). "Products: Teknocoat Aqua Primer 1866-05 - Karta techniczna produktu [Technical data sheet], Karta charakterystyki [Safety data sheet]," (https://www.teknos.com/document/tds/pl_1866-05_2.pdf), Accessed 13 Sept 2020.

Teknos (2020g). "Products: Teknocoat Aqua 2575-32 - Karta techniczna produktu [Technical data sheet], Karta charakterystyki [Safety data sheet]," (https://www.teknos.com/pl-PL/produkty/teknocoat-aqua-2575-32/), Accessed 13 Sept 2020. 
Teknos (2020h). "UVILUX 6450 - Karta techniczna produktu [Technical data sheet]," (https://www.teknos.com/document/tds/pl_6450-03_1.pdf), Accessed 13 Sept 2020.

Ugulino, B., and Hernandez, R. E. (2016). "Analysis of sanding parameters on surface properties and coating performance of red oak wood," Wood Mater. Sci. Eng. 13(2), 64-72. DOI: 10.1080/17480272.2016.12 66511

Yu, X., Xu, D., Sun, Y., Geng, Y., Fan, J., Dai, X., He, Z., Dong, X., Dong, Y., and Li, Y. (2020). "Preparation of wood-based panel composites with poplar veneer as the surface layer modified by in-situ polymerization of active monomers," Forests 11(8), Article number 893. DOI: 10.3390/f11080893

Zbieć, M., Borysiuk, P., and Mazurek, A. (2010). "Polyethylene bonded composite chipboard Part 2 Machining tests," in: Proceedings of the $7^{\text {th }}$ International Science Conference. Chip and Chipless Woodworking Processes, Terchova, Slovakia, pp. 237-242.

Article submitted: November 15, 2020; Peer review completed: January 31, 2021;

Revised version received: February 16, 2021; Accepted: February 17, 2021; Published: February 22, 2021.

DOI: 10.15376/biores.16.2.2696-2713 